ZOOLOGIA 28 (5): 629-640, October, 2011

doi: $10.1590 /$ S1984-46702011000500011

\title{
Birds from open environments in the caatinga from state of Alagoas, northeastern Brazil
}

\author{
Helder Farias Pereira de Araujo ${ }^{1} \&$ Roberta Costa Rodrigues ${ }^{2}$
}

\author{
1 Departamento de Ciências Biológicas, Centro de Ciências Agrárias, Universidade Federal da Paraíba. Campus II, \\ 58397-000 Areia, PB, Brazil.E-mail: hfparaujo@yahoo.com.br \\ 2 Programa de Pós-Graduação em Biologia Animal, Universidade Federal de Pernambuco. Cidade Universitária, \\ 50670-901 Recife, PE, Brazil. E-mail: robertacrodrigues@gmail.com
}

\begin{abstract}
Even though the caatinga has been identified as an important area of endemism for South American birds, few studies have been conducted on the distribution, evolution and ecology of birds in this biome. Understanding how habitats contribute to maintain the regional bird diversity is extremely important. In this study, carried out in the backwoods of the state of Alagoas, we present a rapid survey of a caatinga area and discuss the composition of the avifauna in different habitats. From the record of 105 species, we estimated a local richness of $120( \pm 5)$ species. Among the areas surveyed, the dense caatinga shrub areas contributed with more than $42 \%$ of the species, holding most of the forest-dependent birds. The open field areas and the vegetation patches contributed 26 and $24 \%$ of the observed richness, respectively. The bird community at the vegetation patches is more similar to that registered in the open caatinga shrub areas, than to the fauna of the open fields where these patches are located. Our results support the need to conserve environments which harbor typical caatinga vegetation, and also vegetation patches with those characteristics in greatly altered environments.
\end{abstract}

KEY WORDS. Avifauna; conservation; habitat preference; species richness.

The caatinga, with an area of $735,000 \mathrm{~km}^{2}$, covers most of the northeastern Brazilian territory. Located between latitudes $2^{\circ} 54^{\prime} \mathrm{S}$ and $17^{\circ} 21^{\prime} \mathrm{S}$, it extends through the dry valley from the middle Jequitinhonha River, in the state of Minas Gerais. The typical caatinga vegetation is characterized by xerophytic, deciduous arboreal and shrub formations, with trees and shrubs bearing thorns (Prado 2003, Leal et al. 2005).

Prado \& Gibbs (1993) characterized the caatingas from the Brazilian Northeast as one of the largest areas of Seasonal Neotropical Dry Forests (SNDF) in South America. Other large SNDFs can be found in Misiones and Piedmont nuclei, and on the Caribbean coasts of Colombia and Venezuela. Smaller and more isolated SNDFs occur in dry valleys in the Andes in northern Bolivia, Peru, southern Ecuador and the adjacent northern Peru, Mato Grosso de Goiás in central Brazil, and scattered throughout the Brazilian Cerrado in areas of fertile soils (RATTER et al. 1978). SNDFs in the Neotropical region also occur in Mesoamerica, and in Florida (Pennington et al. 2006).

The diversity, species richness and number of endemic species in the caatinga region have for a long time been considered low (e.g., Vanzolini et al. 1980, Andrade-Lima 1982, Prance 1987). However, some recent studies have revealed significantly higher species richness in the region. As a consequence, the need to preserve this important component of the Brazilian biodiversity has been widely acknowledged (LeaL et al. 2003, SiLva et al. 2004, Leal et al. 2005). The true number of species in the caatinga region, however, is potentially much greater than the present estimates, because $41 \%$ of the region has never been surveyed, and $80 \%$ of it has been only poorly investigated (Tabarelli \& Vicente 2004).

Even though the caatinga has been identified as an important area of endemism for South American birds (Muller 1973, Cracraft 1985, Haffer 1985, Rizzini 1997), the distribution, evolution and ecology of its avifauna have been poorly investigated (Silva et al. 2003).

Recently, SANTOS (2004) discussed the ecological preferences of birds in two caatinga physiognomies in the state of Piauí. Olmos et al. (2005) also discussed and compared the avifauna in different physiognomies in the states of Pernambuco and Ceará. However, our knowledge of how bird diversity is maintained in different caatinga environments is still incipient. This biome has a variety of habitats and is subjected to extensive anthropic alterations.

In this study we present the results of a rapid survey in a caatinga area in the backwoods of the state of Alagoas, and discus the avifauna composition of the different environments we found. 


\section{MATERIAL AND METHODS}

We carried out our sampling at the adjacencies of the BR-316 road between the cities of Canapi and Inaja $\left(37^{\circ} 40^{\prime} 21^{\prime \prime} \mathrm{W}\right.$ and $\left.9^{\circ} 5^{\prime} 55^{\prime \prime} \mathrm{S}\right)$, at the borders between the states of Alagoas and Pernambuco, at an area of approximately $63 \mathrm{~km}$ (Fig. 1). This area is inserted among the caatinga eco-regions from Planalto da Borborema and Depressão Sertaneja Sentetrional. It is also adjacent to the Raso da Catarina region (Veloso et al. 2002).

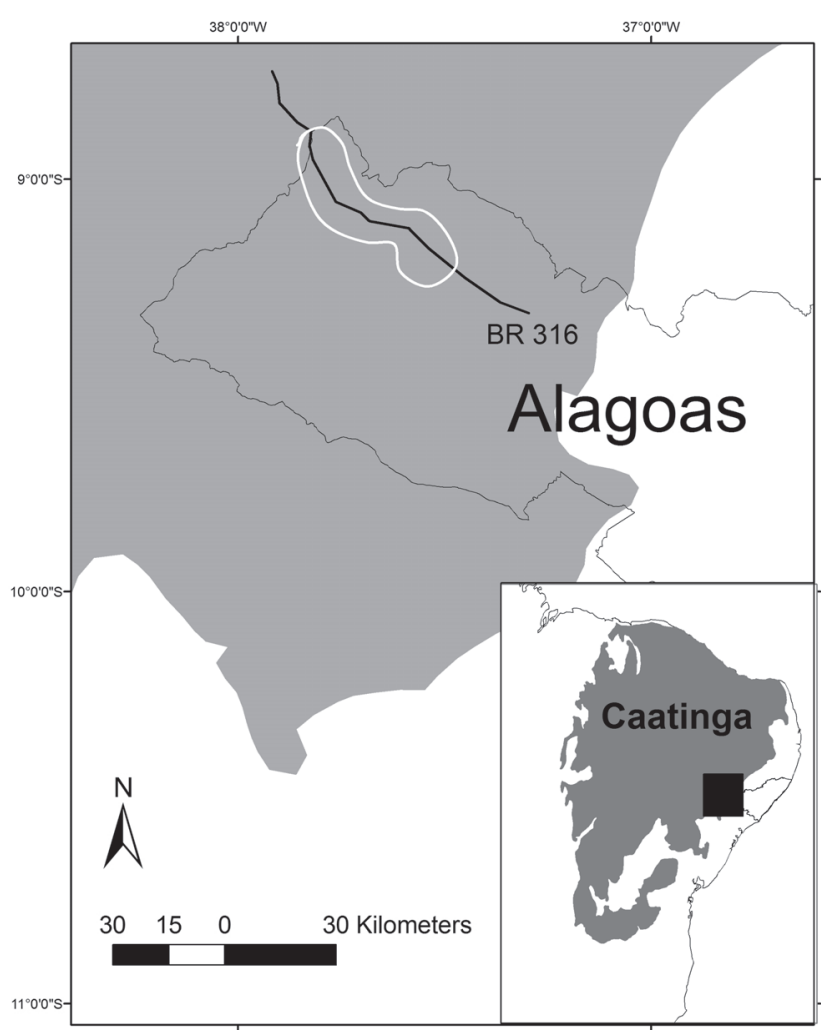

Figure 1. Location of the study area. BR 316 (black line) and sampled area (white line) are detached.

Our sampling sites broadly correspond to two physiognomic landscapes. In the northern part of the road, on the mountains, the caatinga has open vegetation with shrubs and small trees, and some larger trees among them. In the surveyed central and southern parts of the road, we find open fields consisting of pastures and subsistence agricultural crops, with some shrub patches (Fig. 2). These open caatinga areas have been altered by wood removal, trails, and the presence of animals such as goats.

Sampling took place in January and May 2008, during the dry and rainy seasons, respectively. We applied 72 point counts, $200 \mathrm{~m}$ apart from one another, each lasting $10 \mathrm{~min}$ -

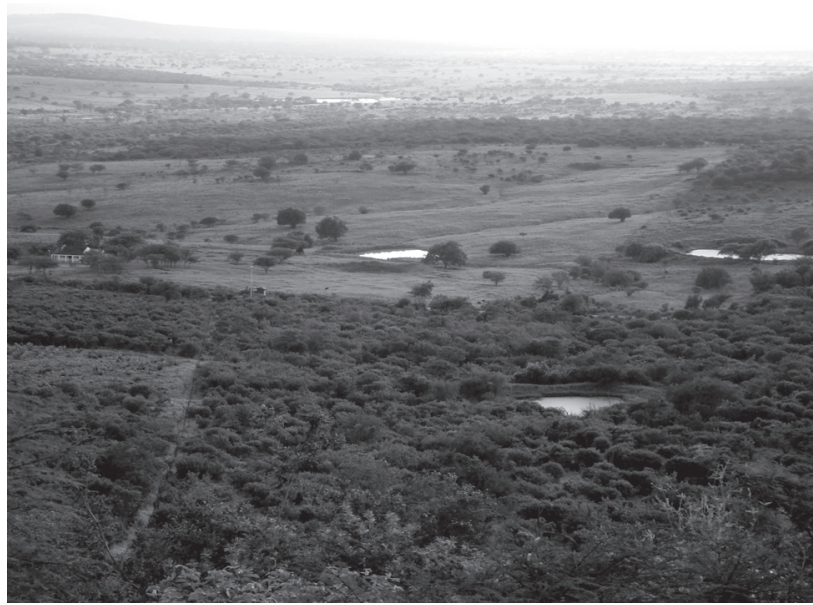

Figure 2. Typical landscape found in the study area, with open caatinga vegetation and open fields used for pasture and agriculture.

utes, totaling 36 point counts in each season. During the point counts, conducted during the first three hours in the morning, sounds and visual records and counts of birds were marked at a $50 \mathrm{~m}$ fixed radius and at an unlimited radius (Adapted from HutTo et al. 1986). We also conducted observations in random spots along the sampled road.

We grouped the recorded species into three categories according to habitat use, as follows: (IND) Independent: species associated only with open vegetation; (SMD) Semi-dependent: species occurring in mosaics formed in the contact areas between forests and open and semi-open vegetation; (DEP) Dependent: species found in forest habitats. Such classification was based on literature information (Silva 1995, STотz et al. 1996, SiLva et al. 2003). Nomenclature follows CBRO (2009).

We calculated the relative abundance (average number of individuals/point X 100) and frequency of occurrence of each species from records obtained within a $50 \mathrm{~m}$ radius, as well as the frequency of occurrence of data from unlimited radius, as recommended in an evaluation of the caatinga by the first author and collaborators (H.F.P. de Araujo unpubl. data).

The total number of species observed at the point counts (Sobs) was represented by a rarefaction curve. The performance of this curve can help estimate the number of species that have not yet been observed in the study area (CHAzDon et al. 1998). To make this estimate, we used the Chao 2 and Jack 1 richness estimators, which have performed better in the caatinga (H.F.P. de Araujo unpubl. data). The rarefaction curve and estimated richness were calculated using the software EstimateS 7.5 (Colwell 2005).

Diversity measures and descriptive statistics were used to compare the avifauna and the percentage distribution of the categories of habitat use in the registered environments. Such environments were classified as: open caatinga (21 point 
counts sampled), open field (23 point counts), shrub patches in open fields (19 point counts) and aquatic environments (9 point counts).

In order to compare the proportion of each bird species in each of the different environment sampled, we used the Shannon's diversity index estimate and 95\% confidence intervals in each habitat. This estimate technique is based on sampling coverage and also includes species which were expected but not sampled (CHAO \& SHEN 2003). These calculations and the Shannon estimates were performed using the SPADE - Species Prediction and Diversity Estimation software program and 95\% confidence intervals (CHAO \& SHeN 2003, 2005).

We compared the avifauna composition among different environments using the Jaccard's similarity index based on estimates, with abundance data. This index was modified from the classical Jaccard index by СнаO et al. (2005). The latter have adapted the Jaccard index to deal with abundance data, and have developed algorithms to calculate similarities between two assemblies that also take into account species which were not sampled. To this procedure uses "singletons" (species represented by only one individual) and "doubletons" (species represented by exactly two individuals). All similarity analysis was performed using the SPADE software. The similarity matrix obtained was subjected to ordination analysis using multidimensional scaling (MDS).

\section{RESULTS}

Using point counts and unsystematic observations, we recorded 105 bird species distributed in 38 families. Tyrannidae, with 20 registered species, was the most ubiquitous family, followed closely by Emberizidae (nine species) and Columbidae (six species).

Using the systematic method of point counts, we counted 97 bird species, representing $93.2 \%$ of the total previously recorded for the area (Appendix 1). The rarefaction curve has shown that more, unrecorded species occur in the study area. However, a total species richness of about $120( \pm 5)$ can be estimated with Chao 2 and Jack 1 estimators (Fig. 3).

The number of species observed in the rainy period represents $90.4 \%$ of the total number of species registered. In the dry season, by contrast, only $76.9 \%$ of the total number of species was found. The abundance curves of the species registered in the two seasons are shown in figure 4. Two species, Sturnella superciliaris (Bonaparte, 1850) and Pitangus sulphuratus (Linnaeus, 1766), were amongst the five most abundant species only in the dry season. Zonotrichia capensis (Statius Muller, 1776) and Sicalis luteola (Sparrman, 1789), by contrast, appeared among the five most abundant during the rainy season only.

We recorded 11 species with restricted distribution in Brazil, according to Ridgely \& Tudor (1994), Sick (1997) and Ridgely et al. (2005). Seven are typical species from the Brazilian Northeast: Caprimulgus hirundinaceus Spix, 1825 - typical species from

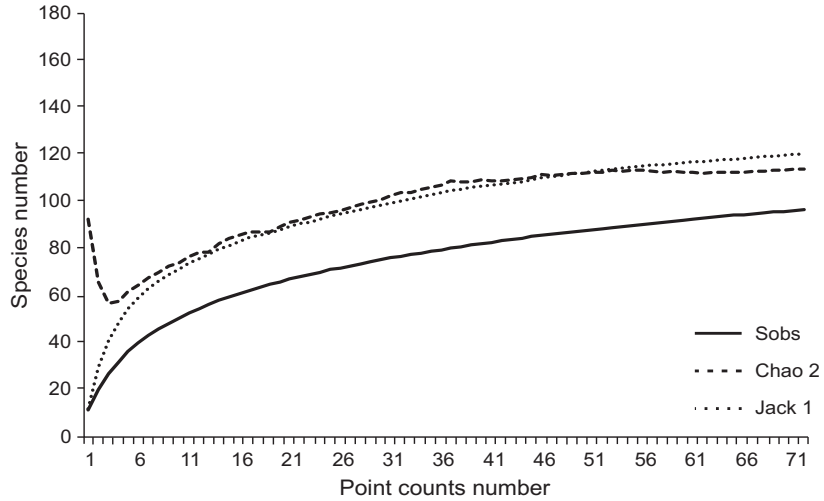

Figure 3. Rarefaction curve (Sobs) and species richness estimates (Chao2 and Jack 1 ) of the birds recorded with point counts.

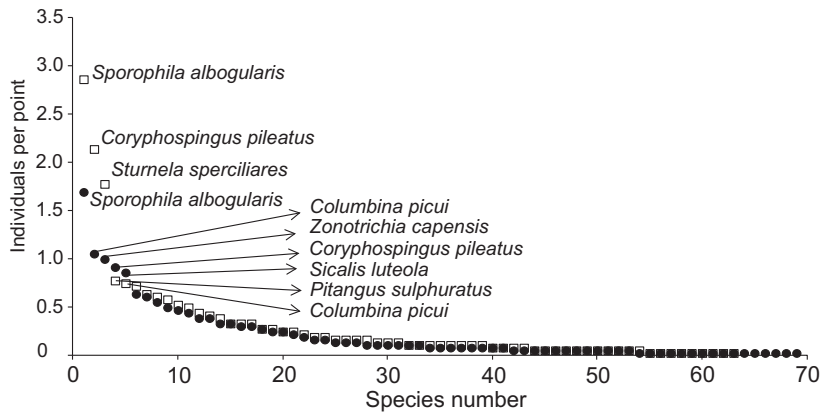

Figure 4. Abundance curve of bird species recorded with point counts (fixed radius of $50 \mathrm{~m}$ ). Dry season (white squares) and rainy season (black circles).

the caatinga region, registered in northern Espírito Santo (RiboN 1995); Pseudoseisura cristata (Spix, 1824) - endemic species which has been separated from the old combination Pseudoseisura cristata unirufa, and which occurs in the Pantanal and in Bolivia (ZiMMER \& WhitTAKER 2000); Thamnophilus capistratus Lesson, 1840 - recently validated within the $T$. doliatus (Linnaeus, 1764) complex (Assis et al. 2007); Compsothraupis loricata (Lichtenstein, 1819); Sporophila albogularis (Spix, 1825) - only two other records are from locations in northern Goiás and Mato Grosso (Silva 1995); Paroaria dominicana (Linnaeus, 1758) and Agelaioides fringillarius (Spix, 1824). Two species are restricted to eastern Brazil: Heliomaster squamosus (Temminck, 1823) and Cantorchilus longirostris (Vieillot, 1819). Two other species have a slightly wider distribution in the Brazilian central-eastern territory: Nystalus maculatus (Gmelin, 1788) and Cyanocorax cyanopogon (Wied, 1821).

The areas from open caatinga have contributed with more than $42 \%$ of the observed species richness. In these areas, most species that are at least partially dependent on forest environments were also observed (Fig. 5). The open fields, and shrub 
patches found in the open fields contributed with about 26 and $24 \%$ of the observed richness, respectively. However, the percentages of species that are at least partially dependent on forests were greater in patches than in open fields (Fig. 5).

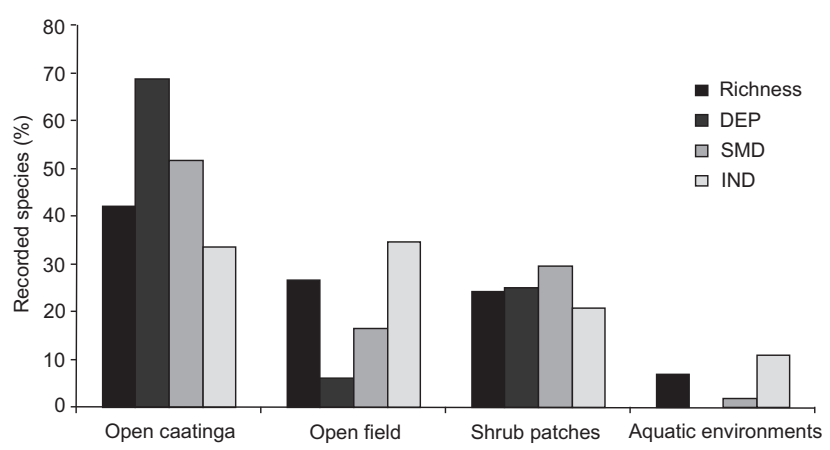

Figure 5. Percentage of species richness and their categories of habitat use in the recorded habitats. Categories of habitat use: IND. forest independent, SMD. forest semi-dependent, DEP. forest dependent.

The estimated diversity index was significantly higher in the open caatinga areas than in any of the other habitats. The values of this index were greater in the open field areas and shrub patches than in the aquatic environments, but did not differ significantly from one another (Fig. 6).

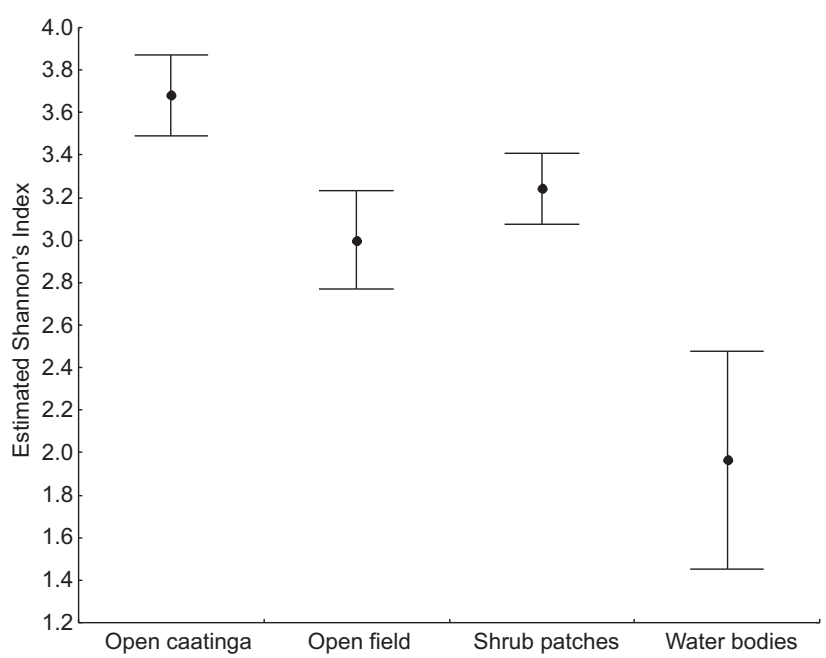

Figure 6. Estimate of Shannon's diversity index of bird species recorded in each environment. The bars indicate the confidence intervals of $95 \%$.

The avifauna composition in the shrub patches was more similar to the avifauna registered in the open caatinga areas than to that found in the open fields where the shrub patches are inserted (Fig. 7). As expected, the avifauna composition of the aquatic environments differed from those of all other habitats the most.

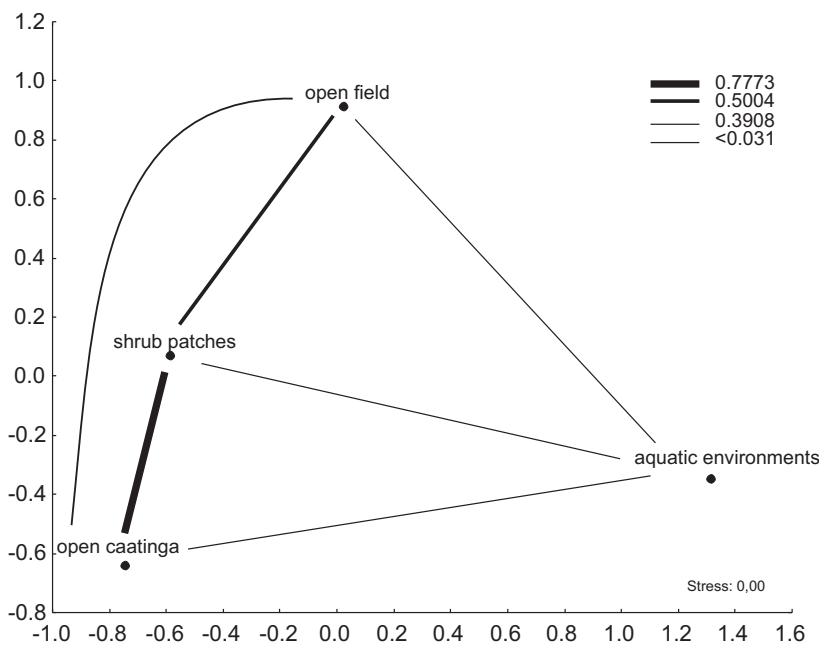

Figure 7. Multidimensional scaling (MDS) with similarity matrix using Jaccard's index estimates with abundance data, of the bird species composition in the each habitat. The thickness of the lines indicates the similarity values that are demonstrated in the legend.

The differences and similarities among open caatinga, shrub patches and open fields can be demonstrated using their most abundant species. Approximately after the $10^{\text {th }}$ most abundant species, there is a sharp fall in the species abundance curves for open field and shrub patches. For this reason, we used the 10 most abundant species to compare among the habitats (Figs 8-11). Four species were among the 10 mostabundant in the three habitats: Columbina picui (Temminck, 1813), Mimus saturninus (Lichtenstein, 1823), Zonotrichia capensis (Statius Muller, 1776) and Sporophila albogularis (Spix, 1825). The abundance curve of the open caatinga area shows a more equitable distribution when compared with the other two habitats. This area has four exclusive species among the 10 most abundant: Pseudoseisura cristata (Spix, 1824), Stigmatura napensis Chapman, 1926, Tyrannus melancholicus Vieillot, 1819 and Progne tapera (Vieillot, 1817). The record of Progne tapera among the most abundant may be the result of the presence of a single flock in the area. The open field area also presents four exclusive species among the 10 most abundant: Pitangus sulphuratus (Linnaeus, 1766), Ammodramus humeralis (Bosc, 1792), Sicalis luteola (Sparrman, 1789) and Sturnella superciliaris (Bonaparte, 1850). Even in the shrub patches, only Polioptila plumbea (Gmelin, 1788) appears exclusively among the 10 most abundant, the others are among the most abundant in both open caatinga and open field areas (Figs 8-11). 

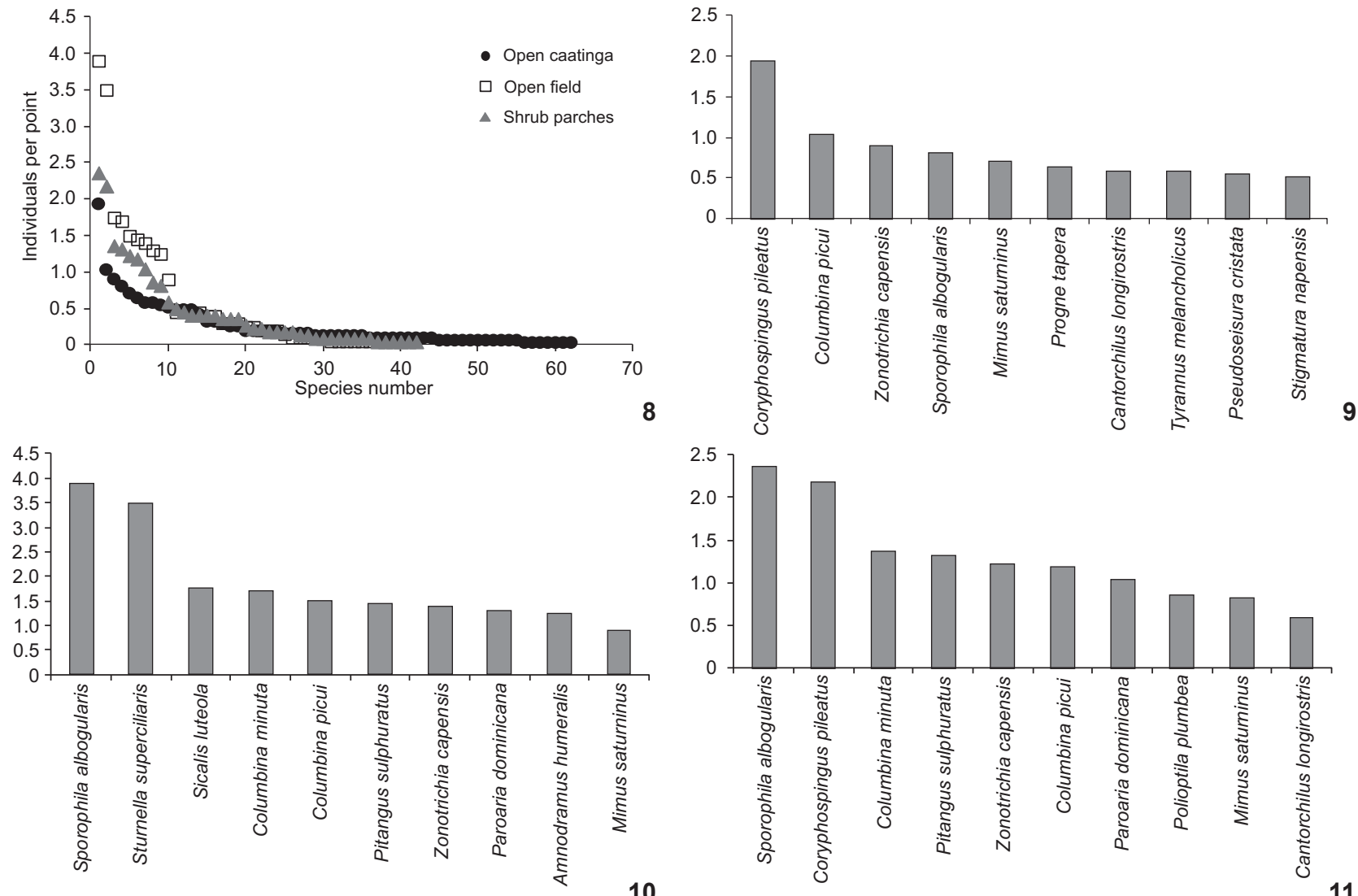

Figures 8-11. (8) Abundance curves of recorded species in each habitat and the ten species more abundant; (9) open caatinga; (10) open field; (11) shrub patches.

\section{DISCUSSION}

The great number of species in Tyrannidae, Emberizidae and Columbidae had been previously observed in other communities in the caatinga by TELINO-JúNIOR et al. (2005) and Roos et al. (2006). NASCIMENTO et al. (2000) and SANTOS (2004) also recorded the Tyrannidae and the Emberizidae among the three largest families in their surveys. However, the Thamnophilidae, Furnariidae, Trochilidae and Accipitridae in the first, and Thamnophilidae, Furnariidae in the second, were better represented than the Columbidae; in Olmos et al. (2005) the Trochilidae was better represented than Emberizidae and Columbidae. In those examples, only in the Chapada do Araripe - Ceará (NASCIMENTo et al. 2000) and areas in Piauí (SANTOS 2004) a pattern for the best represented families that resembles the pattern found for the entire caatinga (SILVA et al. 2003) has been found. Thus, even though some species seem to occur only in certain areas and have restricted distribution, they are important representatives of the regional richness.

The estimated richness of $120(+5)$ species is comparable to that found in previous surveys conducted in areas of the caatinga. Bird counts in protected areas, however, have revealed a higher richness of species, as follows: Olmos (1993) registered 208 species in Serra da Capivara, Piauí; NAscimento et al. (2000) registered 193 species in Chapada do Araripe; NASCIMENTO (2000) registered 154 in the Estação Ecológica de Aiuaba, Ceará; Lima et al. (2003) registered 191 in the Raso da Catarina, Bahia; TelinoJUNior et al. (2005) have registered 145 species in a private reserve in the state of Paraíba; and Farias et al. (2006) registered 193 species in Serra das Almas, Ceará. Also, higher species richness (155 species) have been reported by SANTOs (2004) for unprotected caatinga areas in Piauí; by Roos et al. (2006) (145 species) in the Sobradinho region, Bahia, and by Farias et al. (2006) (65species) in Betânia, Pernambuco. In the Ecological Station from Seridó, Rio Grande do Norte, NASCimento (2000) registered 116 bird species, a number similar to ours. However, when our results are compared with the species richness estimated for other locations under human impact, they are equivalent or lower. For instance, Olmos et al. (2005) after surveying eight areas in the states of Ceará and Pernambuco, found 96, 109, 102, 101, 72, 93, 94 and 125 species; Farias et al. (2006) found 94 species in the Curimataú, Paraíba; and Farias (2007) 
listed 106 in Caraíbas, 92 in Brígida, 58 in Icó Mandante and 56 species in Apolônio Sales, Pernambuco. Even though these comparisons may not be appropriate because curves based on effort and/or estimates is lacking for several contributions, they offer an overview of the distribution of species richness in a geographical scale, which is consistent with the conservation status of different areas.

Species that varied considerably in abundance between the dry and rainy season, for instance $S$. superciliaris, $P$. sulphuratus, Z. capensis and S. luteola, are not known to be migratory. Their variation in abundance can be explained by changes in their spatial distribution between seasons. Some species may be found grouped in habitats where resources are concentrated during the dry period and spaced across the landscape in the rainy season, when resources and humidity are more widely available (SILVA et al. 2003, Olmos et al. 2005). However, our results have revealed the importance of conducting systematic studies over a longer period of time in the caatinga in order to understand more fully the dynamics of frequency and abundance of bird species.

Our lack of knowledge about inter-tropical migrations and other smaller scale displacements makes it difficult for us to classify the species we found as migratory with broad displacements, or small seasonal migrants in the caatinga region (Olmos et al. 2005). However, 18 species recorded by us either performed displacements related to water availability, or are known to be migratory:

- Tachybaptus dominicus (Linnaeus, 1766), Porphyrio martinica (Linnaeus, 1766), Megaceryle torquta (Linnaeus, 1766), Chloroceryle americana (Gmelin, 1788) and Fluvicola albiventer (Spix, 1825) are species associated with aquatic environments and only occurred in the study area during the rainy season.

- Zenaida auriculata (Des Murs, 1847), in spite the few individuals spotted in the two sampling periods, is a typical migratory species in the caatinga, performing displacements according to the rain (Azevedo Júnior \& Antas 1990). Personal observations in the state of Paraíba have registered large flocks of $Z$. auriculata in the second half and in the end of the rainy season, when seeds, an important dietary item for the species, are more widely available. The fact that sampling in Alagoas occurred in the first half of the rainy season may explain the observation of only a few individuals of this species.

- Coccyzus melacoryphus Vieillot, 1817, Myiopagis viridicata (Vieillot, 1817), Euscarthmus meloryphus Wied, 1831, Cnemotriccus fuscatus (Wied, 1831) and Pachyramphus polychopterus (Vieillot, 1818) are species that migrate among different areas in the Neotropical region, they occurred mainly in the caatinga during the rainy season.

- Five Tyrannidae species registered, Elaenia spectabilis Pelzeln, 1868, Camptostoma obsoletum (Temminck, 1824), Phaeomyias murina (Spix, 1825), Empidonomus varius (Vieillot, 1818) and
Tyrannus melancholicus Vieillot, 1819 are mentioned in the literature as migratory. However, their higher frequencies in the dry season may have resulted from the fact that they passed through the study area just before the beginning of the rainy season, because sampling in the dry season was performed near the beginning of the rainy season in the region.

- The hummingbird Chrysolampis mosquitus (Linnaeus, 1758) and the bay-winged Agelaioides fringillarius (Spix, 1824) were seen during the rainy season. Due to variations in their abundance and frequency in the area and in other caatinga areas (personal observations), we suggest that displacements in these two species are seasonal.

- Volatinia jacarina (Linnaeus, 1766) varied in abundance and frequency, and were observed more often during the rainy season; therefore, we suggest that displacements of this species are seasonal, as mentioned by Olmos et al. (2005).

Other species registered only in one sampling period, for instance Patagioenas picazuro (Temminck, 1813) and Leptotila verreauxi Bonaparte, 1855, are more prone to local displacements to habitats where water and resources concentrate than to wider migrations (pers. obs.). The low richness or abundance of aquatic species in caatinga areas is most likely due to the scarcity of aquatic environments (Olmos et al. 2005). The open caatinga from the backwoods of Alagoas maintains greater bird diversity, with almost twice as many species as registered in open fields, or in the small shrub patches found in these fields. A more equitable distribution of the abundance curve of birds that occur in areas of open caatinga shows a greater heterogeneity in the community and supports the idea that this environment is the most diverse among the three evaluated.

Olmos et al. (2005) commented that some species which are endemic or almost endemic to the caatinga seem to benefit from anthropogenic habitats, where their populations are denser. They mention $P$. dominicana and $A$. fringillarius as examples. In our study area, $P$. dominicana was among the ten most abundant in the open fields and shrub patches, but was the $25^{\text {th }}$ in abundance in the open caatinga. Sporophila albogularis, which was more abundant in the open fields and shrub patches, had a similar abundance value as other most abundant species in the open caatinga.

SANTOS (2004) demonstrated a clear difference in the composition of bird species between arboreal and shrub physiognomies in a caatinga area in the state of Piauí; Olmos et al. (2005) registered species found only in arboreal formations or forests, and species which benefit from anthropogenic habitats in caatinga areas in the states of Pernambuco and Ceará; in this study, we observed a clear distinction among the studied habitats, even in the open fields which have been differently impacted by human occupation. These results do reinforce the need to conserve environments that include the typical caatinga vegetation, both for maintaining the \pm diversity and the species which are endemic to these environments. The 
maintenance of vegetation patches in altered habitats may also help some species which occur in forest areas and do not thrive in areas as open fields used for pasture and agriculture.

The results of this study also suggest that researchers trying to evaluate species richness or similarities in the composition of the avifauna at a regional scale within a historical framework should take into consideration the fact that some places in the caatinga have been altered to the point that they longer harbor their original fauna.

\section{ACKNOWLEDGEMENTS}

This study was conducted as part of the environmental assessment to evaluate the impact of the proposed paving of BR 316 carried by Consultoria Ambiental Ltda and ECOPLAN Engenharia Ltda. We thank Emmerson Santos and Gentil Filho by suggestions in the English text.

\section{LITERATURE CITED}

Andrade-Lima, D. 1982 Present-day forest refuges in northeastern Brazil, p. 123-135. In: G.T. Prance (Ed.). Biological diversification in the tropics. New York, Columbia University Press.

Assis, C.; M. Raposo; R. Stopiglia \& R. Parrini. 2007. Validation of Thamnophilus capistratus Lesson, 1840 (Passeriformes: Thamnophilidae). The Auk 124 (2): 665-676.

Azevedo Júnior, S.M \& P.T. Antas. 1990. Novas informações sobre a alimentação de Zenaida auriculata no Nordeste do Brasil, p. 59-64. In: Anais do IV Encontro Nacional dos Anilhadores de Aves. Recife.

CBRO. 2009. Lista das aves do Brasil. Comitê Brasileiro de Registros Ornitológicos. Available online at: http:// www.cbro.org.br/CBRO/listabr.htm [Acessed in 05/X/2009]

Chao, A. \& T.J. Shen. 2003. Nonparametric estimation of Shannon's index of diversity when there are unseen species en sample. Environmental and Ecological Statistcs 10: 429-443.

Chao, A. \& T.J. Shen. 2005. Program SPADE (species prediction and diversity estimation). Program and user's guide. (20032005). Available online at: http://chao.stat.nthu.edu.tw [Acessed in 15/XI/2009]

Chao, A.; R.L. Chazdon; R.K. Colwell \& T.J. Shen. 2005. A new statistical approach forassessing similarity of species composition with incidence and abundance data. Ecology Letters 8: 148-159.

Chazdon, R.L.; R.K. Colwell; J.S. Denslow \& M.R. Guariguata. 1998. Statistical methods for estimating species richness of woody regeneration in primary and secondary rain forests of NE Costa Rica, p. 285-309. In: F. DALlmeier \& J.A. ComisKey (Eds). Forest biodiversity research, monitoring and modeling: Conceptual background and Old World case studies. Paris, Parthenon Publishing.
Colwell, R.K. 2005. User's guide to EstimateS7.5 statistical. Estimation of species richness and shared species from samples. Version 7.5.

Cracraft, J. 1985. Historical biogeography and patterns of differentiation within the South American avifauna: areas of endemism. Ornithological Monographs 36: 49-84.

FARIAS, G.B. 2007. Avifauna em quatro áreas de caatinga strictu senso no centro-oeste de Pernambuco, Brasil. Revista Brasileira de Ornitologia 15: 53-60.

Farias, G.B.; W.A. Girão e Silva \& C.G. Albano. 2006. Diversidade de aves em áreas prioritárias para conservação de aves da Caatinga, p. 204-226. In: F.S. Araujo, M.J.N. Rodal \& M.R.V. BARbosa (Eds). Análise das variações da biodiversidade do bioma caatinga. Suporte a estratégias regionais de conservação. Brasília, Ministério do Meio Ambiente.

HAFFer, J. 1985. Avian zoogeography of the Neotropical lowland. Ornithological Monographys 39: 113-146

Hutto, R.L.; S.M. Pletschet \& P. Hendricks. 1986. A fixed-radius point count method for nonbreeding and breeding season use. The Auk 103: 593-602.

Leal, I.R.; M. Tabarelli \& J.M.C. Silva. 2003. Ecologia e conservação da Caatinga. Recife, Editora Universitária, Universidade Federal de Pernambuco.

Leal, I.R.; J.M.C. Silva; M. Tabarelli \& T.E. Lacher. 2005. Changing the course of biodiversity conservation in the Caatinga of Northeastern Brazil. Conservation Biology 19 (3): 701-706.

Lima, C.P.; S.S. Santos \& R.C. Lima. 2003. Levantamento e anilhamento da ornitofauna na pátria da arara-azul-de-Lear (Anodorhynchus leari, Bonaparte, 1856): um complemento ao levantamento realizado por H. Sick, L. P. Gonzaga e D. M. Teixeira, 1987. Atualidades Ornitológicas 112: 11-22

Muller, P. 1973. Dispersal centers of terrestrial vertebrates in the Neotropical. Biogeografica 2: 1-244.

NASCimENTO, J.L.X. 2000. Estudo comparativo em duas Estações Ecológicas da Caatinga: Aiuaba e Seridó. Melopsittacus 3: 12-35.

Nascimento, J.L.X.; I.L.S. Nascimento \& S.M. Azevedo-Júnior. 2000. Aves da Chapada do Araripe (Brasil): biologia e conservação. Ararajuba 8: 115-125.

Olmos, F. 1993. Birds of Serra da Capivara National Park, in "caatinga" of north-eastern Brazil. Bird Conservation International 3: 21-36.

Olmos, F.; W.A. Girão e Silva \& C.G. Albano. 2005. Aves de oito áreas de Caatinga no sul do Ceará e oeste de Pernambuco, Nordeste do Brasil: composição, riqueza e similaridade. Papéis Avulsos de Zoologia 45 (14): 179-199.

Pennington, R.T.; G.P. Lewis \& J.A. RatTer. 2006. An overview of the plant diversity, biogeography and conservation of Neotropical Savannas and Seasonally Dry Forests, p. 1-29. In: R.T. Pennington, G.P. Lewis \& J.A. Ratter (Eds). Neotropical Savannas and Seasonally Dry Forests: plant diversity, biogeography and conservation. New York, CRC Press Taylor \& Francis Group. 
Prado, D. 2003. As caatingas da América do Sul, p. 3-73. In: I.R. LeAL, M. Tabarelli \& J.M.C. DA Silva (Eds). Ecologia e conservação da Caatinga. Recife, Editora Universitária, Universidade Federal de Pernambuco.

Prado, D.E. \& P.E. Gibbs. 1993. Patterns of species distributions in the dry seasonal forests of South America. Annals of the Missouri Botanical Garden 80: 902-927.

Prance, G.T. 1987. Vegetation, p. 28-45. In: T.C. Whitmore \& G. T. Prance (Eds). Biogeography and Quaternary history in tropical America. Oxford Science Publications.

Ratter, J.A.; G.P. Askew; R. Montgomery \& D.R. Gifford. 1978. Observations on forests of some mesotrophic soils in central Brazil. Revista Brasileira de Botânica 1: 47-58.

RiBon, R. 1995. Nova subspécie de Caprimulgus (Linnaeus) (Aves, Caprimulgidae) do Espírito Santo, Brasil. Revista Brasileira de Zoologia 12 (2): 229-232.

Ridgely, R.S. \& G. Tudor. 1994. The Birds of South America: The Suboscine Passerines. Austin, University Texas Press, vol. 2.

Ridgely, R.S.; T.F. Allnutt; T. Brooks; D.K. McNicol; D.W. Mehlman; B.E. Young \& J.R. Zook. 2005. Digital Distribution Maps of the Birds of the Western Hemisphere. Arlington, NatureServe, version 2.1.

RizzinI, C.T. 1997. Tratado de Fitogeografia do Brasil. Rio de Janeiro, Editora Âmbito Cultural, $2^{\text {nd }}$ ed.

Roos, A.L.; M.F.C. Nunes; E.A. SouzA; A.E.B.A. SouzA; J.L.X. NASCIMENTO \& R.C.A. LACERDA. 2006. Avifauna da região do Lago de Sobradinho: composição, riqueza e biologia. Ornithologia 1 (2): 135-160.

SANTOS, M.P.D. 2004. As comunidades de aves em duas fisionomias da vegetação da Caatinga no estado do Piauí, Brasil. Ararajuba 12 (2): 113-123.

SICK, H. 1997. Ornitologia brasileira. Rio de Janeiro, Nova Fron- teira.

Silva, J.M.C. 1995. Birds of the Cerrado Region, South America. Steenstrupia 21: 69-92.

Silva, J.M.C.; M.A. Souza; A.G.D. Bieber \& C.J. Carlos. 2003. Aves da Caatinga: status, uso do habitat e sensitividade, p. 237273. In: I.R. LEAL; M. TABarelli \& J.M.C. DA Silva (Eds). Ecologia e Conservação da Caatinga. Recife, Editora Universitária da Universidade Federal de Pernambuco.

Silva, J.M.C.; M. Tabarelli; M.T. Fonseca \& L. Lins. 2004. Biodiversidade da Caatinga: áreas prioritárias para conservação. Brasília, Ministério do Meio Ambiente.

Stotz, B.F.; J.W. Fitzpatrick; T.A. Parker III \& D.K. Moskovitz. 1996. Neotropical birds: Ecology and Conservation. Chicago, University Chicago Press.

Tabarelli, M. \& A. Vicente. 2004. Conhecimento sobre plantas lenhosas da Caatinga: lacunas geográficas e ecológicas, p. 101-111. In: J.M.C. DA SiLVA; M. TABARELli; M.T. FonseCa \& M.T. LINs (Eds). Biodiversidade da Caatinga: áreas prioritárias para conservação. Brasília, Ministério do Meio Ambiente.

Telino-Júnior, W.R.; R.M. Lyra-Neves \& J.L.X. Nascimento. 2005. Biologia e composição da avifauna em uma Reserva Particular de Patrimônio Natural da caatinga paraibana. Ornithologia 1 (1): 49-57.

Vanzolini, P.E.; A.M.M. Ramos-Costa \& L.J. VitT. 1980. Répteis das Caatingas. Rio de Janeiro, Academia Brasileira de Ciências.

Veloso, A.L.; E.V.S.B. Sampaio \& F.G.C. Pareyn. 2002. Ecorregiões propostas para o Bioma Caatinga. Recife, Associação Plantas do Nordeste, Instituto de Conservação Ambiental, The Nature Conservancy do Brasil.

Zimmer, K.J. \& A. Whittaker. 2000. The Rufous Cacholote (Furnariidae: Pseudoseisura) is two species. The Condor 102: 409-422.

Submitted: 26.V.2010; Accepted: 11.I.2011. Editorial responsibility: Kleber Del Claro 
Appendix 1. Bird species recorded along the BR 316 road in the west of state of Alagoas, northeast Brazil. Record: S. sound, V. visual. Environment: habitat where the species occurred: (1) open caatinga, (2) open fields, (3) shrub patches, (4) aquatic environments. Habitat use: (IND) forest independent, (SMD) forest semi-dependent, (DEP) forest dependent. Med/pont: individuals number per point in the $50 \mathrm{~m}$ radius $(\mathrm{x} 100)$; freq. $(50 \mathrm{~m})$ : proportion of point counts in which the species was detected within the $50 \mathrm{~m}$ radius; freq.(ilim.): proportion of point counts in which the species was detected in the unlimited radius. The ' $x$ ' marked in some freq(ilim.) fields corresponds to the occurrence record in samplings of the respective periods but out of the point counts.

\begin{tabular}{|c|c|c|c|c|c|c|c|c|c|}
\hline \multirow{2}{*}{ Taxon } & \multirow{2}{*}{ Record } & \multirow{2}{*}{ Environment } & \multirow{2}{*}{ Habit. Use- } & \multicolumn{2}{|c|}{ Dry season } & \multicolumn{4}{|c|}{ Rainy season } \\
\hline & & & & med/pont & freq. $(50 \mathrm{~m})$ & freq.(ilim.) & med/pont & freq. $(50 \mathrm{~m})$ & freq.(ilim.) \\
\hline \multicolumn{10}{|l|}{ Tinamidae } \\
\hline Crypturellus parvirostris (Wagler, 1827) & $S$ & 2 & IND & 0.03 & 2.78 & 8.33 & & & 16.67 \\
\hline Crypturellus tataupa (Temminck, 1815) & VS & 13 & DEP & & & 8.33 & 0.06 & 5.56 & 19.44 \\
\hline Nothura boraquira (Spix, 1825) & S & 3 & SMD & & & & & & 5.56 \\
\hline \multicolumn{10}{|l|}{ Podicipedidae } \\
\hline Tachybaptus dominicus (Linnaeus, 1766) & $\mathrm{v}$ & 4 & IND & & & & & & $x$ \\
\hline \multicolumn{10}{|l|}{ Ardeidae } \\
\hline Butorides striata (Linnaeus, 1758) & VS & 4 & IND & & & 2.78 & & & $\mathrm{x}$ \\
\hline Bubulcus ibis (Linnaeus, 1758) & $\mathrm{v}$ & 2 & IND & & & 2.78 & & & $x$ \\
\hline Ardea alba Linnaeus, 1758 & $\mathrm{v}$ & 4 & IND & & & 8.33 & & & $\mathrm{x}$ \\
\hline Egretta thula (Molina, 1782) & V & 4 & IND & & & $x$ & & & $\mathrm{x}$ \\
\hline \multicolumn{10}{|l|}{ Cathartidae } \\
\hline Cathartes aura (Linnaeus, 1758) & $\mathrm{v}$ & 12 & IND & 0.11 & 8.33 & 8.33 & & & 2.78 \\
\hline Cathartes burrovianus Cassin, 1845 & $\mathrm{v}$ & 12 & IND & 0.03 & 2.78 & 2.78 & 0.03 & 2.78 & 2.78 \\
\hline Coragyps atratus (Bechstein, 1793) & v & 12 & IND & 0.06 & 2.78 & 5.56 & 0.08 & 2.78 & 2.78 \\
\hline \multicolumn{10}{|l|}{ Accipitridae } \\
\hline Elanus leucurus (Vieillot, 1818) & $\mathrm{v}$ & 12 & IND & 0.03 & 2.78 & 2.78 & & & \\
\hline Rupornis magnirostris (Gmelin, 1788) & VS & 12 & IND & 0.14 & 11.11 & 13.89 & 0.08 & 8.33 & 16.67 \\
\hline \multicolumn{10}{|l|}{ Falconidae } \\
\hline Caracara plancus (Miller, 1777) & VS & 12 & IND & 0.11 & 8.33 & 13.89 & & & 5.56 \\
\hline Herpetotheres cachinnans (Linnaeus, 1758) & S & 1 & SMD & & & & & & 5.56 \\
\hline Falco sparverius Linnaeus, 1758 & VS & 2 & IND & & & $x$ & 0.06 & 5.56 & 5.56 \\
\hline \multicolumn{10}{|l|}{ Rallidae } \\
\hline Porphyrio martinica (Linnaeus, 1766) & $\mathrm{v}$ & 4 & IND & & & & & & $x$ \\
\hline \multicolumn{10}{|l|}{ Cariamidae } \\
\hline Cariama cristata (Linnaeus, 1766) & S & 1 & IND & & & & 0.06 & 2.78 & 2.78 \\
\hline \multicolumn{10}{|l|}{ Charadriidae } \\
\hline Vanellus chilensis (Molina, 1782) & VS & 24 & IND & & & 13.89 & 0.11 & 5.56 & 30.56 \\
\hline \multicolumn{10}{|l|}{ Jacanidae } \\
\hline Jacana jacana (Linnaeus, 1766) & $\mathrm{v}$ & 4 & IND & & & $x$ & & & $x$ \\
\hline \multicolumn{10}{|l|}{ Columbidae } \\
\hline Columbina minuta (Linnaeus, 1766) & vS & 13 & IND & 0.72 & 27.78 & 27.78 & 0.50 & 27.78 & 30.56 \\
\hline Columbina squammata (Lesson, 1831) & S & 1 & IND & & & & & & 2.78 \\
\hline Columbina picui (Temminck, 1813) & VS & 13 & IND & 0.75 & 30.56 & 44.44 & 1.06 & 47.22 & 58.33 \\
\hline Patagioenas picazuro (Temminck, 1813) & $S$ & 1 & SMD & & & & 0.08 & 2.78 & 2.78 \\
\hline Zenaida auriculata (Des Murs, 1847) & $\mathrm{v}$ & 23 & IND & & & $x$ & & & $x$ \\
\hline Leptotila verreauxi Bonaparte, 1855 & S & 1 & SMD & & & & 0.08 & 8.33 & 8.33 \\
\hline \multicolumn{10}{|l|}{ Psittacidae } \\
\hline Forpus xanthopterygius (Spix, 1824) & vS & 12 & IND & 0.11 & 5.56 & 11.11 & 0.33 & 11.11 & 13.89 \\
\hline
\end{tabular}


Appendix 1. Continued

\begin{tabular}{|c|c|c|c|c|c|c|c|c|c|}
\hline \multirow{2}{*}{ Taxon } & \multirow{2}{*}{ Record } & \multirow{2}{*}{ Environment } & \multirow{2}{*}{ Habit. Use } & \multicolumn{2}{|c|}{ Dry season } & \multicolumn{4}{|c|}{ Rainy season } \\
\hline & & & & $\mathrm{med} /$ pont & freq. $(50 \mathrm{~m})$ & freq.(ilim.) & med/pon & freq. $(50 \mathrm{~m})$ & freq.(ilim.) \\
\hline \multicolumn{10}{|l|}{ Cuculidae } \\
\hline Coccyzus melacoryphus Vieillot, 1817 & S & 13 & SMD & & & 2.78 & 0.06 & 2.78 & 5.56 \\
\hline Crotophaga ani Linnaeus, 1758 & vS & 2 & IND & & & 2.78 & 0.06 & 2.78 & 16.67 \\
\hline Guira guira (Gmelin, 1788) & VS & 2 & IND & 0.06 & 2.78 & 11.11 & 0.14 & 5.56 & 11.11 \\
\hline Tapera naevia (Linnaeus, 1766) & $\mathrm{s}$ & 12 & IND & & & 2.78 & 0.03 & 2.78 & 11.11 \\
\hline \multicolumn{10}{|l|}{ Strigidae } \\
\hline Athene cunicularia (Molina, 1782) & VS & 12 & IND & & & 2.78 & 0.03 & 2.78 & 2.78 \\
\hline \multicolumn{10}{|l|}{ Caprimulgidae } \\
\hline Caprimulgus hirundinaceus Spix, 1825 & $\mathrm{~V}$ & 1 & IND & & & & & & $\mathrm{x}$ \\
\hline \multicolumn{10}{|l|}{ Trochilidae } \\
\hline Eupetomena macroura (Gmelin, 1788) & V & 12 & IND & 0.08 & 8.33 & 8.33 & 0.03 & 2.78 & 2.78 \\
\hline Chrysolampis mosquitus (Linnaeus, 1758) & v & 1 & IND & & & & 0.06 & 5.56 & 5.56 \\
\hline Chlorostilbon lucidus (Shaw, 1812) & VS & 12 & SMD & 0.25 & 25.00 & 25.00 & 0.28 & 25.00 & 27.78 \\
\hline Amazilia sp. & v & 3 & $?$ & 0.03 & 2.78 & 2.78 & & & \\
\hline Heliomaster squamosus (Temminck, 1823) & vS & 1 & DEP & & & & 0.03 & 2.78 & 2.78 \\
\hline \multicolumn{10}{|l|}{ Alcedinidae } \\
\hline Megaceryle torquata (Linnaeus, 1766) & VS & 4 & IND & & & & & & 2.78 \\
\hline Chloroceryle americana (Gmelin, 1788) & VS & 4 & SMD & & & & 0.03 & 2.78 & 2.78 \\
\hline \multicolumn{10}{|l|}{ Bucconidae } \\
\hline Nystalus maculatus (Gmelin, 1788) & vs & 123 & SMD & 0.11 & 8.33 & 30.56 & 0.19 & 16.67 & 33.33 \\
\hline \multicolumn{10}{|l|}{ Picidae } \\
\hline Veniliornis passerinus (Linnaeus, 1766) & vs & 1 & SMD & 0.06 & 5.56 & 13.89 & 0.08 & 8.33 & 8.33 \\
\hline Colaptes melanochloros (Gmelin, 1788) & $\mathrm{V}$ & 1 & SMD & & & $\mathrm{x}$ & & & \\
\hline \multicolumn{10}{|l|}{ Thamnophilidae Swainson, 1824} \\
\hline Thamnophilus capistratus (Lesson, 1840) & VS & 13 & SMD & 0.19 & 16.67 & 25.00 & 0.11 & 8.33 & 25.00 \\
\hline Myrmorchilus strigilatus (Wied, 1831) & S & 13 & SMD & 0.17 & 13.89 & 30.56 & 0.06 & 5.56 & 13.89 \\
\hline Formicivora melanogaster Pelzeln, 1868 & vS & 13 & SMD & 0.33 & 33.33 & 36.11 & 0.25 & 16.67 & 19.44 \\
\hline \multicolumn{10}{|l|}{ Dendrocolaptidae } \\
\hline Lepidocolaptes angustirostris (Vieillot, 1818) & vs & 13 & IND & 0.06 & 5.56 & 8.33 & 0.06 & 5.56 & 5.56 \\
\hline \multicolumn{10}{|l|}{ Furnariidae } \\
\hline Furnarius leucopus Swainson, 1838 & $\mathrm{~s}$ & 1 & SMD & & & 2.78 & & & $x$ \\
\hline Synallaxis frontalis Pelzeln, 1859 & S & 1 & DEP & & & & 0.03 & 2.78 & 2.78 \\
\hline Synallaxis albescens Temminck, 1823 & vs & 13 & IND & & & & 0.14 & 8.33 & 8.33 \\
\hline Phacellodomus rufifrons (Wied, 1821) & $S$ & 13 & SMD & 0.06 & 2.78 & 5.56 & & & 2.78 \\
\hline Pseudoseisura cristata (Spix, 1824) & vs & 123 & IND & 0.39 & 19.44 & 58.33 & 0.33 & 13.89 & 38.89 \\
\hline \multicolumn{10}{|l|}{ Tyrannidae } \\
\hline $\begin{array}{l}\text { Hemitriccus margaritaceiventer (d'Orbigny e } \\
\text { Lafresnaye, 1837) }\end{array}$ & vs & 13 & SMD & 0.14 & 13.89 & 13.89 & 0.11 & 11.11 & 11.11 \\
\hline Todirostrum cinereum (Linnaeus, 1766) & VS & 12 & SMD & 0.28 & 25.00 & 25.00 & 0.17 & 16.67 & 16.67 \\
\hline Phyllomyias fasciatus (Thunberg, 1822) & VS & 1 & SMD & & & & & & 2.78 \\
\hline Myiopagis viridicata (Vieillot, 1817) & vS & 1 & DEP & & & & 0.08 & 5.56 & 5.56 \\
\hline Elaenia flavogaster (Thunberg, 1822) & $\mathrm{s}$ & 13 & SMD & 0.06 & 2.78 & 2.78 & & & $x$ \\
\hline Elaenia spectabilis Pelzeln, 1868 & $\mathrm{~s}$ & 13 & DEP & 0.08 & 8.33 & 8.33 & 0.06 & 5.56 & 5.56 \\
\hline
\end{tabular}


Appendix 1. Continued.

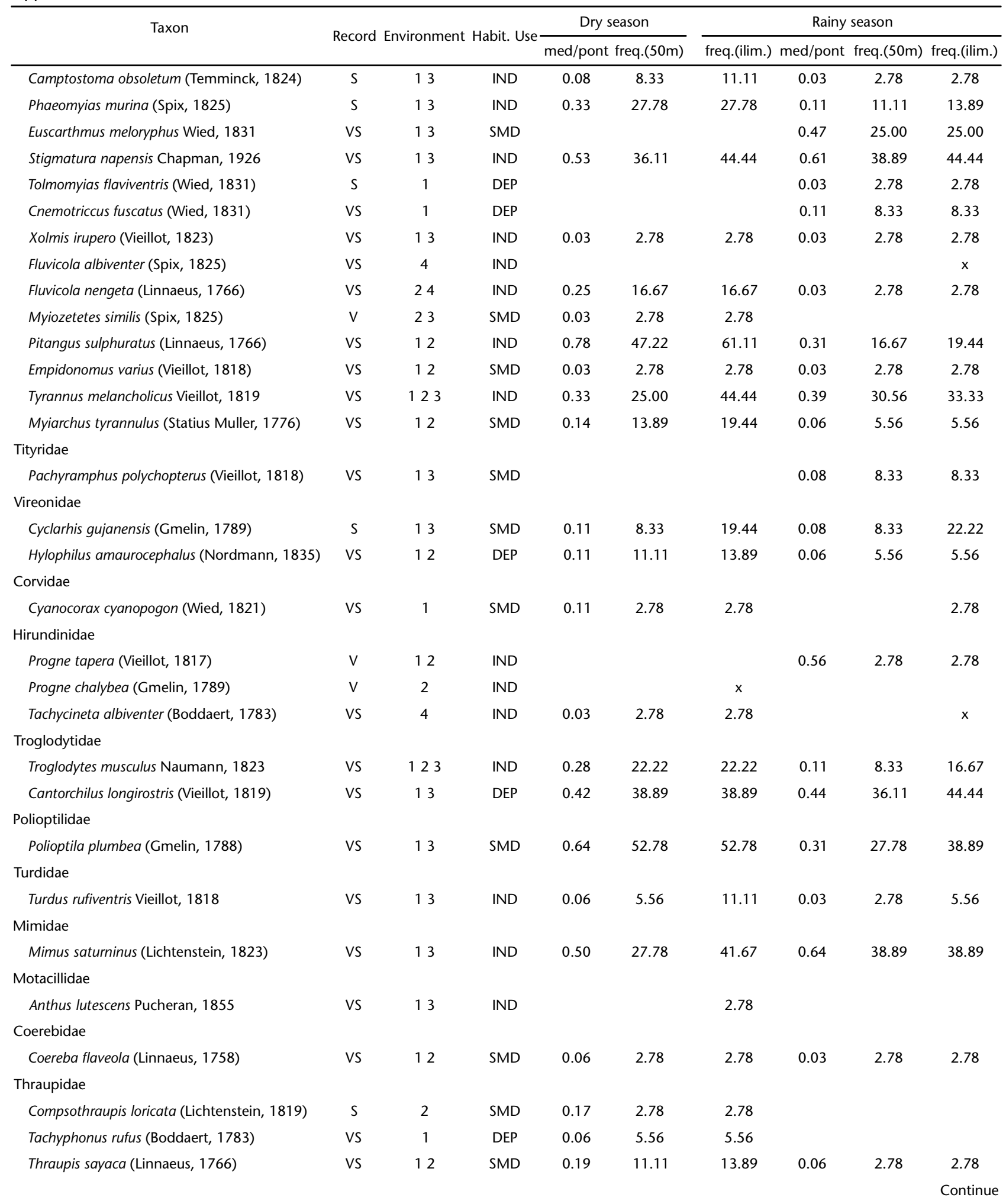


Appendix 1. Continued.

\begin{tabular}{|c|c|c|c|c|c|c|c|c|c|}
\hline \multirow{2}{*}{ Taxon } & \multirow{2}{*}{ Record } & \multirow{2}{*}{ Environment } & \multirow{2}{*}{ Habit. Use } & \multicolumn{2}{|c|}{ Dry season } & \multicolumn{4}{|c|}{ Rainy season } \\
\hline & & & & $\mathrm{med} / \mathrm{pon}$ & eq. $(50 \mathrm{~m})$ & freq.(ilim.) & med/pont & freq. $(50 \mathrm{~m})$ & freq.(ilim.) \\
\hline \multicolumn{10}{|l|}{ Emberizidae } \\
\hline Zonotrichia capensis (Statius Muller, 1776) & vS & 123 & IND & 0.58 & 38.89 & 41.67 & 1.00 & 61.11 & 75.00 \\
\hline Ammodramus humeralis (Bosc, 1792) & vs & 2 & IND & 0.44 & 25.00 & 38.89 & 0.39 & 36.11 & 44.44 \\
\hline Sicalis flaveola (Linnaeus, 1766) & vs & 2 & IND & & & & & & $x$ \\
\hline Sicalis luteola (Sparrman, 1789) & vS & 23 & IND & 0.22 & 2.78 & 2.78 & 0.86 & 19.44 & 19.44 \\
\hline Volatinia jacarina (Linnaeus, 1766) & vS & 23 & IND & 0.06 & 5.56 & 5.56 & 0.22 & 16.67 & 16.67 \\
\hline Sporophila albogularis (Spix, 1825) & vS & 123 & IND & 2.86 & 38.89 & 41.67 & 1.69 & 50.00 & 50.00 \\
\hline Sporophila bouvreuil (Statius Muller, 1776) & VS & 2 & IND & 0.03 & 2.78 & 2.78 & & & \\
\hline Coryphospingus pileatus (Wied, 1821) & vs & 13 & SMD & 2.14 & 72.22 & 72.22 & 0.92 & 41.67 & 44.44 \\
\hline Paroaria dominicana (Linnaeus, 1758) & vs & 123 & IND & 0.61 & 27.78 & 30.56 & 0.25 & 19.44 & 22.22 \\
\hline \multicolumn{10}{|l|}{ Cardinalidae } \\
\hline Cyanoloxia brissonii (Lichtenstein, 1823) & vs & 13 & DEP & 0.06 & 5.56 & 5.56 & 0.03 & 2.78 & 2.78 \\
\hline \multicolumn{10}{|l|}{ Icteridae } \\
\hline Icterus cayanensis (Linnaeus, 1766) & vs & 13 & SMD & 0.08 & 5.56 & 5.56 & & & $x$ \\
\hline Agelaioides fringillarius (Spix 1824) & vS & 2 & IND & & & & 0.17 & 2.78 & 2.78 \\
\hline Molothrus bonariensis (Gmelin, 1789) & vs & 12 & IND & 0.17 & 5.56 & 5.56 & & & $x$ \\
\hline Sturnella superciliaris (Bonaparte, 1850) & vs & 2 & IND & 1.78 & 16.67 & 16.67 & 0.14 & 5.56 & 8.33 \\
\hline \multicolumn{10}{|l|}{ Fringillidae } \\
\hline Euphonia chlorotica (Linnaeus, 1766) & vS & 13 & IND & 0.11 & 8.33 & 13.89 & 0.03 & 2.78 & 5.56 \\
\hline \multicolumn{10}{|l|}{ Passeridae } \\
\hline Passer domesticus (Linnaeus, 1758) & $\mathrm{V}$ & 2 & IND & 0.17 & 2.78 & 2.78 & & & $x$ \\
\hline
\end{tabular}

